\title{
Effects of riociguat in severe experimental pulmonary hypertension
}

\author{
Baktybek Kojonazarov ${ }^{1 *}$, Michaela Lang ${ }^{1}$, Norbert Weissmann ${ }^{1}$, Friedrich Grimminger ${ }^{1}$, Johannes-Peter Stasch², \\ Werner Seeger ${ }^{1,3}$, Hossein Ardeschir Ghofrani ${ }^{1}$, Ralph Schermuly ${ }^{1,3}$ \\ From 5th International Conference on cGMP: Generators, Effectors and Therapeutic Implications \\ Halle, Germany. 24-26 June 2011
}

\section{Introduction}

The NO-sGC-cGMP signaling pathway is impaired in different cardiovascular diseases, including pulmonary hypertension $(\mathrm{PH})$. Riociguat is the first of a new class of drugs, the soluble guanylate cyclase stimulators. Riociguat has a dual mode of action: it sensitizes sGC to the body's own $\mathrm{NO}$ and can also increase sGC activity in the absence of $\mathrm{NO}$, causing vasorelaxation, anti-proliferation and anti-fibrotic effects.

The aim of the study was to investigate the effects of riociguat as compared to the PDE5 inhibitor sildenafil on pulmonary vascular remodeling in severe experimental $\mathrm{PH}$.

\section{Methods}

Angioproliferative $\mathrm{PH}$ was induced in rats by combined exposure to the vascular endothelial growth factorreceptor antagonist SU5416 and hypoxia at 10\%O2 (SU + HOX). Twenty-one days thereafter, rats were randomized for treatment with riociguat $(10 \mathrm{mg} / \mathrm{kg})$, sildenafil $(50 \mathrm{mg} / \mathrm{kg}$ ) or vehicle for the next 14 days. Echocardiography and invasive hemodynamic measurements were performed. Pulmonary vascular remodeling was assessed by histomorphometric analysis.

\section{Results}

In rats with established $\mathrm{PH}$, right ventricular systolic pressure (RVSP) was significantly decreased by treatment with riociguat to $73 \pm 4 \mathrm{mmHg}(\mathrm{p}<0.01)$ and sildenafil to $80 \pm 3 \mathrm{mmHg}(\mathrm{p}<0.05)$ as compared to placebo $(89 \pm 3 \mathrm{mmHg})$. No significant difference in systemic arterial pressure was detected between placebo and treated animals. Both compounds significantly decreased RV

\footnotetext{
* Correspondence: Baktybek.Kojonazarov@Innere.med.uni-giessen.de

'University of Giessen Lung Center, Giessen, Germany

Full list of author information is available at the end of the article
}

hypertrophy and improved RV function by normalization of TAPSE and myocardial performance index, but effects of riociguat were more pronounced. Riociguat significantly reduced the proportion of occluded arteries and increased proportion of opened arteries and decreased neointima/media ratio.

\section{Conclusion}

We demonstrated that riociguat effectively suppresses pulmonary vascular remodeling and significantly improves $\mathrm{RV}$ function in an experimental model of severe $\mathrm{PH}$.

\section{Author details}

${ }^{1}$ University of Giessen Lung Center, Giessen, Germany. ${ }^{2}$ Bayer HealthCare, Wuppertal, Germany. ${ }^{3}$ Department of Lung Development and Remodeling, Max-Planck Institute for Heart and Lung Research, Bad Nauheim, Germany.

Published: 1 August 2011

doi:10.1186/1471-2210-11-S1-P39

Cite this article as: Kojonazarov et al.: Effects of riociguat in severe experimental pulmonary hypertension. BMC Pharmacology 2011 11(Suppl 1):P39.

Submit your next manuscript to BioMed Central and take full advantage of:

- Convenient online submission

- Thorough peer review

- No space constraints or color figure charges

- Immediate publication on acceptance

- Inclusion in PubMed, CAS, Scopus and Google Scholar

- Research which is freely available for redistribution

Submit your manuscript at www.biomedcentral.com/submit
() Biomed Central

\section{(Ciomed Central}

